\title{
BOOK REVIEWS AND NOTES
}

\section{doi:10.1017/S0009640716000834}

\section{Women in Christian Traditions. By Rebecca Moore. Women in}

Religions 1. New York: New York University Press, 2015. ix + 209

pp. $\$ 65.00$ cloth; $\$ 17.00$ paper.

Women in Christian Traditions is the first in a projected twelve-volume series on women in various religions; its author, Rebecca Moore, is a Professor of Religious Studies at San Diego State University. The book is short-less than 150 pages of actual text - and intended primarily for college courses. Nonetheless, its objectives are ambitious: to cover two millennia of Christian history, and to examine its subject through the lenses of feminist scholarship and analysis. The result is work that is frustrating in that it achieves a good deal-but could have achieved a good deal more.

The volume's temporal sweep is perhaps its greatest strength. Beginning with Biblical and patristic times, Moore is quite effective in her consideration of the roles of Eve (both in creation accounts and in foundational Christian belief) and the various Marys, especially the mother of Jesus and the Magdalene, in the Christian scriptures (both canonical and non). She does a good job of explaining how the domestic center of early Christian praxis served to privilege the participation of women, and how the increasing institutionalization and clericalization of worship seriously undermined their roles. There is also excellent analysis of controversies, both contemporary and scholarly, over the matter of virginity and chastity; did they empower women by offering an autonomy that wives could not exercise, or did they deprive women of fulfillment and choices in ways that men were exempt from? It is in these early chapters that Moore most persuasively engages, and sometimes challenges, many threads of feminist scholarship. She does so clearly and non-polemically, helping to make her case accessible to a spectrum of readers.

Moore also selects some interesting examples to illustrate her account. Readers are introduced to persons such as Perpetua and Felicitas, early Christian martyrs (58), although here, as elsewhere, it might have deepened the narrative to have grappled with the class difference between mistress and slave more explicitly. She also discusses Hrotsvitha of Gandersheim (77), a medieval monastic and playwright; Hildegard of Bingen, abbess, physician, and composer (78-79); and Sor Juana Inés de la Cruz, an early modern 
Mexican scholar and monastic (101-103). It is sometimes unclear if these exemplars are being presented as somehow representative of their times and circumstances; perhaps more "ordinary women" would have enriched and complicated the story even further.

In other respects, Moore is less successful. For example, her book begins with an explanation of what feminist scholarship is, particularly as it relates to the study of religion. She is careful to define a number of technical words, including eschatology and soteriology, in ways accessible to undergraduates and nonspecialists. This is all to the good. But concepts fundamental to feminist theory (such as intersectionality, agency, and othering) or to feminist theology (such as kyriarchy) are curiously omitted. Similarly, although the work is framed as being comprehensive and inclusive, it is overwhelmingly Western in focus; even Orthodoxy gets only cursory attention. There is almost no consideration of the Southern hemisphere (where, as Moore acknowledges [147] the majority of Christians live today), and of non-white persons as actors. Most, though not all, references to Asian, African, Latina, and Indigenous people present them primarily as objects of missionary attention, rather than as actors with intrinsic agency. This seems inconsistent with feminist praxis.

There are also some frustrating errors. Simone Weil, for instance, never converted to Catholicism (129), and Dorothy Day was not shaped by or associated with the "Social Gospel" movement (131). While medieval abbesses exercised a certain authority over many aspects of their monasteries, such as double houses that included men, they never "provided the services of clergy" (78), or again "most if not all of the duties of priests" (136), as Moore claims. And while apostolic sisters during the Counter-Reformation were sometimes called "filles séculières," it is incorrect to refer to vowed religious as "seculars" or, for example, to all members of Mary Ward's Institute of the Blessed Virgin Mary as "lay sisters" (104), as this meant something every different in religious life. To be sure, such terminology can be highly specific and technical, and is often bewildering. But misusing it is problematic and misleading; perhaps a reading of Elizabeth Rapley's The Dévotes would have been helpful here.

The book includes a lengthy bibliography, both "works cited" and "for additional reading," and questions for discussion. But the references are curiously dated. Fewer than $30 \%$ of the works cited, and $25 \%$ of the additional reading (the lists overlap) were published in the $21^{\text {st }}$ century, and citations from feminist scholarly journals (Journal of Feminist Studies in Religion, Signs, and so on) - or even acknowledgments that such periodicals exist-are not to be found. Thus a lot of cutting edge work, including much of what focuses on global concerns and non-Western peoples, is absent from consideration or recommendation.

It is to be hoped that this book can serve as foundational to a revised edition with updated and more inclusive references, elimination of factual glitches, and 
more attention to intersectionality and global considerations. Moore writes well and there is no doubt that she is capable of engaging and informing a wide spectrum of readers.

Margaret Susan Thompson

Syracuse University

doi:10.1017/S0009640716000846

\begin{abstract}
John Chrysostom on Divine Pedagogy: The Coherence of his Theology and Preaching. By David Rylaarsdam. Oxford Early

Christian Studies. Oxford: Oxford University Press, 2014. xxvi +317

pp. $\$ 105.00$ cloth.
\end{abstract}

This is an excellent contribution to the current reassessment of John Chrysostom's writings. The author has perceived the importance to Chrysostom of the principle of "adaptability" or "accommodation" (synkatabasis) in his understanding of the way in which God deals with the human race and the way therefore in which Christians must witness to the Gospel with which they have been entrusted. The author offers a thorough and extremely helpful review of the extent to which the principle informed the oratory and pedagogy of the classical and late antique culture in which Christianity grew up in a relationship of occasionally fruitful rivalry. Chrysostom maintains, against the Eunomians, that while God (or at least the divine essence) cannot be known, the divine goodness has chosen to manifest itself in ways adapted or accommodated to the various conditions of the human race in the different times of its history: the supreme example of the adaptation to students practiced by all competent teachers. All teachers, from the master craftsman to the philosopher, seek to bring about some improvement in their pupils, and Chrysostom understands the divine dispensation as the great pedagogical project encompassing the human race throughout its history. $\mathrm{He}$ also sees the apostle Paul, the supremely accomplished imitator of God's pedagogy, as the model which he is to follow in his own ministry.

One of the most interesting aspects of the book is its illustration of the extent to which the classical model of oratory and pedagogy influenced Chrysostom's assumptions about how God deals with humankind. God is the great Teacher, the supremely wise and skilled Educator, whose practice of adaptation displays a range of strategies perfectly suited to the varieties of human beings, their cultures, and their moral states. The book shows how well Chrysostom thought that Paul had learned this, and how determined he was to mold himself upon the apostle's example. His practice of adaptation in his homilies had as one of its chief purposes to encourage his listeners to adopt 